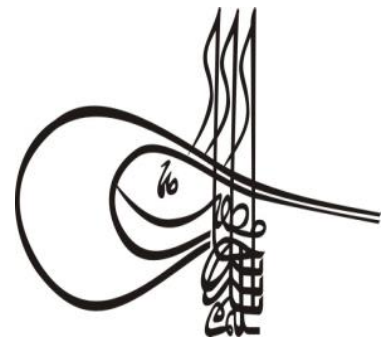

Received/Geliș: 20.07.2019

Gonort Dates/Rapor Tarihleri: Referee 1 (08.12.2019)-Referee 2 (20.12.2019)

\section{Turkigh Stutíes \\ Social Sciences}

Volume 14 Issue 6, 2019, p. 2981-2998

DOI: 10.29228/TurkishStudies. 24972

ISSN: 2667-5617

Skopje/MACEDONIA-Ankara/TURKEY
Research Article / Araştırma Makalesi

Article Info/Makale Bilgisi

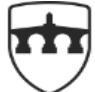

INTERNATIONAL

BALKAN

UNIVERSITY

EXCELLENCE FOR THE FUTURE IBU.EDU.MK

$\checkmark$ Accepted/Kabul: 25.12.2019

This article was checked by intihal.net.

\title{
DEMOGRAFİK DEĞİŞKENLERİN İŞYERİ YALNIZLIĞINA ETKİLERİ: HİZMET SEKTÖRÜNDE BİR ARAŞTIRMA
}

\author{
Mihriban CINDILLĞLU DEMIRER
}

\begin{abstract}
öz
Çalışmanın amacı, işyeri yalnızlığının demografik değişkenlere göre farklılıklarının olup olmadığını belirlemektir. Araştırmanın örneklemini hizmet sektöründe çalışan 211 beyaz yakalı personel oluşturmaktadır. Çalışmada işyeri yalnızlığı kavramı sosyal arkadaşlık ve duygusal yoksunluk olmak üzere iki boyutta incelenmiştir. Öncelikle işyeri yalnızlığı kavramı açıklanmış olup, kavramla ilgili yapılmış çalışmalara yer verilmiştir. Ardından kavramı demografik değişkenler üzerinde inceleyen çalışmalara yer verilmiştir. Araștırmanın yöntemi başlığ1 altında, işyeri yalnızlığını ölçen ölçekler değerlendirilmiş olup, çalışmada kullanılan, Wright, Burt ve Strongman (2006) tarafından geliştirilmiş "İş Yeri Yalnızlı̆̆ı" ölçeğinin geçerlilik ve güvenilirlik analizleri de yapılmıştır. Analiz sonucunda ortaya çıkan uyum iyiliği değerleri Wright ve arkadaşları (2006) tarafindan yapılan DFA analizi ile karşılaştırmalı olarak incelenmiştir. Demografik değişkenler yaş, cinsiyet, eğitim, medeni durum, idarecilik ve mesleki deneyim olarak belirlenmiştir. Çalışmada demografik değişkenler ile işyeri yalnızlığı arasında fark olup olmadığını analiz etmek için, Mann Whitney U-Testi ve Kruskal Wallis HTesti analizleri yapılmıştır. Çalışmada, işyeri yalnızlığının demografik değişkenler üzerinde yapılmış diğer araştırmalarada yer verilmiştir. Analiz sonuçlarına göre, bu örneklem üzerinde işyeri yalnızlı̆̆ ile belirlenen demografik değişkenler arasında anlamlı bir fark bulunamamiștır. Bu bulgulara göre, kurulan $\mathrm{H} 1, \mathrm{H} 2, \mathrm{H} 3, \mathrm{H} 4, \mathrm{H} 5$ ve H6 hipotezleri reddedilmiştir. Elde edilen sonuçlarla ilgili yorumlar ilgili başlikta ve sonuç bölümünde yorumlanmıștır. Yine bulgular, daha önce yapılmış araştırmalarla desteklenerek sonuç kısmında konu edilmiştir. Sonuç bölümünde ileride yapılacak çalışmalara önerilerde bulunularak araştırmanın kısıtları ile ilgili de bilgi verilmiștir.
\end{abstract}


Anahtar Kelimeler: İşyeri yalnızlığı, sosyal arkadaşlık, duygusal yoksunluk, geçerlilik, demografik değişkenler

\title{
THE IMPACTS OF DEMOGRAPHIC VARIABLES ON WORKPLACE LONELINESS: A RESEARCH IN THE SERVICE SECTOR
}

\begin{abstract}
The aim of the study was to determine whether workplace loneliness differs according to demographic variables. The sample of the study consists of 211 white collar personnel working in the service sector. The concept of workplace loneliness was examined in two dimensions as social friendship and emotional deprivation. Firstly, the concept of workplace loneliness has been explained and the studies about the concept have been included. Then, studies examining the concept of demographic variables are included. The scales measuring workplace loneliness were evaluated under the title of the research method and validity and reliability analyzes of the "Workplace Loneliness" scale developed by Wright, Burt, and Strongman (2006) were also performed. The goodness of fit results obtained from the analysis was compared with Wright et al. (2006) in comparison with DFA analysis. Demographic variables were determined as age, gender, education, marital status, management, and professional experience. In this study, Mann Whitney U-Test and Kruskal Wallis H-Test were used to analyzing the differences between demographic variables and workplace loneliness. Other studies on demographic variables of workplace loneliness were also included. According to the analysis results, no significant difference was found between the loneliness and demographic variables determined in this sample. According to these findings, established hypothesis H1, H2, H3, $\mathrm{H} 4, \mathrm{H} 5$, and $\mathrm{H} 6$ were rejected. The comments about the results were interpreted in the related title and results section. Again, the findings are supported by previous researches and discussed in the conclusion. In the conclusion part, suggestions were given to future studies and information about the limitations of the research was also given.
\end{abstract}

\section{STRUCTURED ABSTRACT}

The concept of loneliness was conceptualized in 1959 by FrommReichman's work "Loneliness". Rogers (1961) "On Encounter Groups", Moustakas (1961) "Loneliness", Bowlby (1969) "Attachment and Loss Dost and Weiss (1973)" Loneliness: The Emotional and Social Isolation "takes place in the literature as the conceptual roots of loneliness. The concept of loneliness can be defined as the negative emotion experienced as a result of the insufficient satisfaction of the individuals' social relationship needs (Öge, Çetin and Top, 2018). In other words, loneliness can be defined as weakness in interpersonal relations and socialization ability (Erns and Cacioppo, 1999). Weiss (1973) stated that loneliness involves both emotional and social isolation. The concept of workplace loneliness is dealt with in two dimensions as "Emotional Deprivation and 
Social Friendship" (Weiss, 1987; Cramer, 2000; Wrigh, 2005; Wright, Burt and Strongman, 2006).

In general, how will we know if employees are alone in organizational environments? This requires a generalizable measurement tool within the organization. In this way, the managers will evaluate the situation of individuals or organization in the organizational environment. In this study, the loneliness situation in the service sector, which should or should be found in interpersonal relations, will be examined within the framework of demographic characteristics. Before this review, the validity and reliability analyses of the "Workplace Loneliness" scale will be conducted. Then, whether there is a relationship between employee perception of loneliness and various demographic factors (such as age, gender, education) and the type and the significance level of this relationship will be determined.

In the literature, it is seen that employee loneliness is examined in terms of demographic variables in educational sciences (Izgar, 2009; Yılmaz and Aslan, 2013; Bakioğlu and Korumaz, 2014; Tabancalı and Korumaz, 2014), in adolescents (Carr and Schellenbach, 1993) and in the studies conducted on the elderly (Creecy, Berg and Wright, 1985; Holmen, Kjerstin, Andersson and Winblad, 1992; Khorshid, Eşer, Zaybak, Yapucu, Arslan and Çınar, 2004). However, no study examining the loneliness of white-collar service sector employees was found. For this reason, it is thought that this study will contribute to the literature related to the originality of the study and the study can answer the issue for both managers and employees.

The validity and reliability methodology of Song, Joo and Chermack (2009), Yang (2003) and Mbassana (2014) were taken as examples to analyze the validity and reliability of the scale of workplace loneliness. The Workplace Loneliness Scale was developed by Wright et al. The study sample Corum in Turkey working in the service sector in the province constitutes 211 white-collar staff. In this study, emotional deprivation was expressed as emotional loneliness and social friendship was expressed as social loneliness.

As a result of exploratory factor analysis, a common factor variances of the items were calculated. It was found that the 2 nd item of the social loneliness dimension was seen in the emotional loneliness factor and the calculated common variance of the item was 0.37 . It was found that the other items were collected under their factors and the common factor variances were 0.46 and above. For these reasons, item 2 of the social loneliness factor was removed and the analysis was continued. As a result, validity and reliability analysis was performed with 15 items. As a result of the analyzes, the validity of the workplace loneliness scale in both two dimensions and one dimension was performed and it was determined that goodness of fit values fit well in both analyzes.

According to the results of the Mann Whitney U-Test, which was conducted to determine whether the study showed significant differences in demographic variables according to gender, marital status and whether they were managers, there was no significant difference between workplace loneliness and workplace loneliness. The results of Kruskal Wallis H-Test, which was conducted to determine whether the

\section{Turkish Studies - Social Sciences}

Volume 14 Issue 6, 2019 
participants showed a significant difference according to their age, educational background, and professional experience, showed that there was no significant difference between workplace loneliness. According to the results $\mathrm{H} 1, \mathrm{H} 2, \mathrm{H} 3, \mathrm{H} 4, \mathrm{H} 5$, and $\mathrm{H} 6$ hypotheses were rejected. It supports the results of some studies. Stroebe Stroebe, Stroebe, Abakoumkin and Schut (1996) concluded that marital status did not affect social loneliness. Mercan, Oyur, Alamur, Gül and Bengül (2012) concluded that emotional deprivation and social friendship did not show a significant difference according to gender and marital status. Y1lmaz and Aslan (2013) concluded that the loneliness of teachers at work did not differ according to the gender variable. There was no significant difference in the emotional deprivation dimension according to marital status. Yüksel, Özcan and Kahraman (2013) found that age variables were not effective on loneliness. They also concluded that marital status did not make a significant difference in terms of loneliness level variable.

According to the results of the difference analysis, there is no difference between workplace loneliness with respect to demographic changes, and the fact that these employees are not usually behind closed doors but on the contrary, they are in constant communication with customers face to face, they do not experience this feeling of loneliness in the workplace. It should also be noted that most service sector transactions require communication. In this communication process, the fact that the employees are in constant communication with them causes them not to feel the feeling of workplace loneliness. The service sector performs most of the transactions between enterprises, individuals, consumers, and customers. This process causes all employees to communicate and communicate continuously with someone regardless of their marital status, age, and gender. This situation may cause employees in this sector not to feel alone in the workplace.

The limitation of this study is that the data were collected from one sector and one province. Due to this constraint, it is not possible to generalize the results. Conducting the study in different provinces and different sectors may allow the results to be compared and interpreted.

Keywords: Workplace loneliness, social companionship, emotional deprivation, validity, demographics variables

\section{Giriş}

Toplumda veya örgütlerde kişiler arası etkileşim iki birey arasında, ekip çalışması veya grupta, formel ve yakın/sosyal ilişkilerde değerlendirilebilir. Bu değerlendirme davranışsal, bilişsel ve duygusal düzeyde yapılmaktadır. Davranışsal düzeyde davranışın türü, kuvveti ile kişilerarası ilişkilerin özellikleri arasında bir bağlantı aranır. Bilişsel düzeyde bireyin algılama, düşünme süreçleri ile tutum ve beklentilerinin özelliklerine dikkat edilir. Duygusal düzeyde ise, bireylerin duygu ve heyecanlarının kişilerle olan ilişkilerindeki ilgisi incelenir (Cüceloğlu, 2017).

Bireyler, örgüt ortamlarında kişiler arası ilişkilerinde uyum ve denge ararlar. Heider, kişiler arası ilişkilerdeki dengeye simetri ve dengeli ilişkileri simetrik ilişkiler şeklinde ifade etmektedir. Bireylerin, simetriyi gerçekleştirmek ve aradaki olumsuz farkı kapatmak için kişiler arası ilişkileri güçlendirip, birbirleri ile iletişim kurmaları gerekmektedir. Bu ilişki sayesinde, bir süre sonra ilişkideki simetri başarılı olacaktır (Cüceloğlu, 2017). Tersi durum ise dengesizlik, olumsuz sonuçlar ve kötü deneyimler ortaya çıkarır. Çünkü bireyleri rahatsız eden dengesizlik onun örgüt ortamında diğerlerinden uzaklaşmasına, onlarla paylaşımlarının azalmasına ve yalnızlığa sürükleyecektir. 
Yalnızlık bireyler arası anlamlı ilişkilerin yokluğu, istenmeyen ve olumsuz bir duygu durumudur (Peplau ve Perlman, 1982). Psikolojik açıdan yalnızlık kişilik, özellikleri, kültürel değerler, normlar, gereksinim duyulan sosyal ilişkiler gibi deneyimler sonucu ortaya çıkan öznel bir durumdur (Çakır ve Çakır, 2011). İşyeri yalnızlığı örgütsel ortamlarda kişilerin birbirleri ile aralarındaki olumsuz algilarda ve bu algı sonucunda kopuk olumsuz duygusal durumlarda, kuramadıkları sosyal ilişkilerde, paylaşım içinde olamayacağı ya da olamadığı ortamlarda kendini göstermektedir. Kısacası bu tür bir yalnızlık hem sosyal ilişkilerdeki memnuniyetsizliği hem de olumsuz duyguları yansıtır. Uzun vadede ele alındığında işyerinde yalnızlık duygusu hem örgüte hem de bireye zarar verici bir hal alabilir. Yöneticilerin bu durumu göz önünde bulundurmaları ve gerekli önlemleri almaları gerekir.

Şunu da ifade etmek gerekir ki, genel olarak baktığımızda çalışanların örgüt ortamlarında yalnız olup olmadıklarını nasıl anlayacağız? Bunun için örgüt içerisinde genellenebilir bir ölçüm aracı kullanmak gerekir. Bu sayede yönetici(ler) örgüt ortamında bireylerin ya da örgütün durumunu değerlendirmiş olacaktır. Bu çalışmada özellikle kişilerarası ilişkilerde bulunması gereken ya da bulunma zorunluluğu olan hizmet sektöründe işyeri yalnızlığı durumu demografik özellikler çerçevesinde incelenecektir. Bu inceleme öncesinde "Iş̧ Yeri Yalnızlığı" ölçeğinin geçerlilik ve güvenilirlik analizleri yapılacaktır. Ardından çalışanların yalnızlık algıları ile çesitli demografik faktörler (yaş, cinsiyet, eğitim gibi) arasında bir ilişkinin olup olmadığını ve var ise bu ilişkinin türü ve anlamlılık düzeyi belirlenecektir.

Literatür incelendiğinde çalışan yalnızlığının demografik değişkenler ile daha çok eğitim bilimlerinde (Izgar, 2009; Yılmaz ve Aslan, 2013; Bakioğlu ve Korumaz, 2014; Tabancalı ve Korumaz, 2014), gençlerin ergenlik dönemlerinde (Carr ve Schellenbach, 1993) ve yaşlılar üzerinde (Creecy, Berg ve Wright, 1985; Holmen, Kjerstin, Andersson ve Winblad, 1992; Khorshıd, Eşer, Zaybak, Yapucu, Arslan ve Çınar, 2004), yapılmış çalışmalara rastlanmıştır. Ancak beyaz yakalı hizmet sektörü çalışanlarının işyeri yalnızlıklarının incelendiği bir çalışmaya rastlanmamıştır. Bu nedenle bu çalışmanın özgünlüğ̈̈ ile ilgili literatüre katkı sağlayacağı ve çalışmanın hem yöneticiler hem de çalışanlar açısından konuya cevap verebileceği düşünülmektedir.

\section{1.İşyeri Yalnızlığı}

Yalnızlık kavramı 1959 yılında Fromn-Reichman'ının "Loneliness-Yalnızlık” başlıklı çalışması ile kavramsallaşmıştır. Rogers'in (1961) "On Encounter Groups-Karşılaşım Gurubu", Moustakas'ın (1961) "Loneliness-Yalnızlık", Bowlby'nin (1969) “Attachment and Loss-Dostluk ve Dokunma" ve Weiss'in (1973) "Loneliness: The Experience of Emotional and Social IsolationYalnızlık: Duygusal ve Sosyal İzolasyon Deneyimi” adlı çalışmalar yalnızlığın kavramsal olarak köklerini oluşturan çalışmalar olarak alanyazında yerini almaktadır. Yalnızlık kavramı, bireylerin sosyal ilişki ihtiyacının tatmin edilememesi sonucunda yaşanan olumsuz duygu olarak tanımlanabilir (Öge vd., 2018). Bir başka ifade ile yalnızlık kişilerarası ilişkilerde ve sosyalleşme yeteneğinde zayıflık olarak tanımlanabilir (Erns ve Cacioppo, 1999).

İşyeri yalnızlığı kavramı ise ilk defa Wright'in doktora tezinde ortaya atılan bir kavramdır. Wright (2005) tezinde işyerinde yalnızlığı öncelikle "Emotional Deprivation - Duygusal yoksunluk" başlı̆̆ı altında ifade etmiştir. İşyeri yalnızlığı örgüt ortamlarında "bireylerin sosyal çevreden kaynaklı tek başına kalma durumu veya bireyin kendisini duygusal olarak tek başına kalmış hissi içerisinde olması" şeklinde tanımlanmaktadır. Bir başka ifade ile işyerindeki ilişkilerin çalışanlar tarafından iyi kalitede olduğu algısının oluşmaması nedeniyle ortaya çıkan sıkıntılı veya olumsuz durum şeklinde ifade edilebilir (Öge vd., 2018).

Weiss (1973) yalnızlık teorisini açıklarken yalnızlığın hem duygusallığı hem de sosyal izolasyonu içerdiğini ifade etmiştir. İş̧yeri yalnızlığı kavramı da "Duygusal Yoksunluk-Emotional 
Deprivation ve Sosyal Arkadaşlık-Social Companionship" olmak üzere iki boyutta ele alınmaktadır (Weiss, 1987; Cramer, 2000; Wrigh, 2005; Wright vd. 2006).

\subsection{Duygusal Yoksunluk}

Duygusal yoksunluk, iş arkadaşlı̆̆ ilişkilerinin niteliksel yönlerini ifade etmektedir. Bu nitelikler, kendini diğerlerine karşı yabancılaşmış, yalıtılmış, herhangi bir bağlantısı olmayan ve duygusal olarak onlara uzak olduğu hissi yaşamayı içermektedir (Wright, 2005).

\subsection{Sosyal Arkadaşlık}

Sosyal arkadaşlık, iş arkadaşlığı ilişkilerinin, niceliksel yönlerini ifade etmektedir. $\mathrm{Bu}$ nicelikler, işyerinde iş arkadaşları ile zaman geçirmek, birbirlerine vakit ayırmak, bir grubun parçası olduğunu hissetmek, sık sık sosyal ortamlarda bulunmak ve güven temelli ilişkiler içinde olmaktır. Bütün bu açıklamalardan yola çıkarak işyerinde yalnızlık, bireyin iş ilişkilerinde duygusal yoksunluk ve sosyal arkadaşlık eksikliği yaşaması olarak tanımlanmaktadır (Wright, 2005).

\section{3.İşyeri Yalnızlığı ile İlgili Yapılmış Çalışmalar}

İşyeri yalnızlı̆̆ı konusu örgütlerde yöneticiler, özellikle insan kaynakları uygulayıcıları, tarafından dikkate alınması gereken önemli bir kavramdır. Bu kavramın sonuçları hem işgörenler hem örgüt açısından olumsuzdur. Çalışanların örgüt ortamlarında bu olumsuz durumla başa çıkmaları, duygusal ve sosyal açıdan yalnızlık duygusu yaşamamaları için yöneticilere büyük görevler düşmektedir. Yöneticilerin, işgörenlerin kendilerini geliştirmeleri yönünde destek olmaları gerekir. İşgörenlerin hem yöneticileri hem de iş arkadaşları tarafindan görüşlerini dinleyen ve anlayan bir iletişim yapısının oluşturulması, sosyal destek ağı, aktiviteler gibi yöntemleri geliştirilmeleri gerekmektedir. Hem işte hem de iş dışında sosyal ilişkilerin geliştirilmesi, kıdemli ve genç çalışanlar arasındaki resmi ilişkilerin geliştirilmesi, ekip çalışması, resmi ve gayrı resmi iletişim kanallarının aktivasyonu, psikolojik ve sosyal destek sunan uzmanların istihdamı gibi yardımlar işyerinde yalnızlığı azaltıcı kurumsal önlemler olarak ifade edilebilir (Kaymaz, vd. 2014: 40). İşyeri yalnızlığının hem örgütsel hem de bireysel sonuçları alanyazında yapılmış birkaç çalışma üzerinden nitelendirilecektir.

Erdil ve Ertosun (2011) çeşitli sektörlerden elde ettikleri verilere göre sosyal iklim çalışan yalnızlığı algısını düşürmektedir. Lam ve Lau (2012) öğretmenler üzerine yaptıkları araştırma sonucuna göre rol performansı ile örgütsel vatandaşlık davranışının negatif yönlü bir ilişki içerisinde olduğunu tespit etmişlerdir. Karakaya, Büyükyılmaz ve Ay'ın (2015) çalışma sonucuna göre duygusal yalnızlığın aşırı çalışma ve zorlayıcı çalışma davranışlarını arttırdığını tespit etmişler ve buna karşılık sosyal yalnızlık ile aşırı çalışma ve zorlayıcı çalışma davranışları arasında anlamlı bir ilişki tespit edilememiştir. Kaymaz ve arkadaşları (2014) özel sektör çalışanları üzerine yaptıkları araştırma sonucuna göre işyeri yalnızlığının işten ayrılma niyetini etkilediğini tespit etmişlerdir. Aşık (2016) otel çalışanları üzerinde yapmış olduğu araştırmada, otel çalışanlarının yalnızlık düzeylerinin orta ve tükenmişlik seviyelerinin yüksek düzeyde olduğu ve yalnızlık ile tükenmişlik arasında orta düzeyde pozitif bir ilişki olduğunu tespit etmiştir. Demirbaş ve Haşit'in (2016) araştırma sonucunda, akademisyenlerin iş yerinde yalnızlık düzeyleri ile işten ayrılma niyetleri arasında anlamlı ve pozitif yönlü orta derece bir ilişkinin olduğu belirlenmiştir. Peng ve arkadaşlarının (2017) işyeri yalnızlığının yaratıcılığı negatif yönde etkilediğini ve lider-üye etkileşiminin bu iki değişken arasında aracılık rolü üstlendiği sonucuna ulaşmışlardır. Akçit ve Barutçu'nun (2017) akademisyenler üzerinde yaptıkları araştırmaya göre, işyeri yalnızlığı algısının iş performansı üzerinde olumsuz etkisi olduğunu tespit etmişlerdir. Cindiloğlu ve arkadaşları (2017), üniversitede çalışan idari personel üzerinde yaptıkları araştırmaya göre, işyeri yalnızlığının lider-üye etkileşimi ile iş ve yaşam tatminini negatif yönde etkilediğini tespit etmişlerdir. Ayrıca lider-üye etkileşiminin işyeri yalnızlığ 1 ile iş ve yaşam tatmini arasındaki ilişki üzerinde aracılık etkisinin olup olmadığını belirlemek 
amacıyla hiyerarşik regresyon analizi yapmışlardır. Bu analiz sonucunda da lider-üye etkileşiminin işyeri yalnızlığı ile iş ve yaşam tatmini üzerindeki etkisinde aracılık rolü olduğu tespit edilmiştir. Amarat ve arkadaşları (2018) yaptıkları çalışmada, hemşirelerin işyeri yalnızlı̆̆ algısının iş performansı üzerinde olumsuz etkisi olduğunu tespit etmişlerdir.

İşyeri yalnızlığının bireysel sonuçlarına baktığımızda bireylerin psikolojik ve öznel iyi olma halini olumsuz yönde etkilemektedir (Bakioğlu ve Korumaz, 2014: 29). Bu olumsuz sonuçlar depresyon, memnuniyetsizlik, sosyal kaygı, üzüntü, endişe, öfke, stres, tükenmişlik gibi psikolojik problemlere yol açabilir (Wright, 2005: 14; Asher ve Paguette, 2003: 75; Rokach ve Brock, 1998). Yine can sıkıntısı, korku, mutsuzluk, uyku ve yeme bozuklukları gibi psikosomatik bozukluklar şeklinde ifade edilebilir (Coşan, 2014: 106). Yalnızlık yaşayan bireylerin fiziksel ve ruhsal anlamda güç kayb1, güven kaybı, karar vermede zorlanma ve bulunduğu ortamdan kaçma gibi sonuçlarla karşılaştığı bilinmektedir. Yalnızlık bireysel açıdan döngüsel bir süreci ifade etmektedir. Yalnız bireyler diğer bireylerle iletişim kurmakta fazlasıyla endişe duymaktadır. Yalnızlık bireylerin diğer bireylere güven duymasına engel olan en güçlü duygulardan biri olarak görülmektedir (Bakioğlu ve Korumaz, 2014: 29). En dikkat çekici olanı ise, yalnız insanların ölüm hızının daha yüksek olmasıdır (Coşan, 2014: 106-108).

\section{4. İşyeri Yalnızlığını Demografik Değişkenler Üzerinde İnceleyen Çalışmalar}

Yalnızlık kavramının bireysel, sosyal ve örgütsel değişkenlerle ilişkisinin olması bireylerin yalnızlık sürecinde tam olarak bir neden-sonuç ilişkisinin doğrusal bir şekilde incelenmesini ve tam olarak anlaşılmasını zorlaştırmaktadır (Tabancalı ve Korumaz, 2014: 32). Birbirinden bağımsız değişkenlerle etkisi ve ilişkisi açıklanmaya çalışılan yalnızlıkla ilgili bu çalışmada, demografik değişkenler ile çalışan yalnızlığ 1 arasında anlamlı bir farklılık olup olmadığı belirlenmeye çalışılacaktır. Bu demografik değişkenler yaş, cinsiyet, eğitim, medeni durum, idarecilik mesleki deneyim ve o işletmedeki çalışma süreleri olarak belirlenmiştir. Yapılan çalışmalar incelediğinde Stroebe, Stroebe, Abakoumkin ve Schut (1996) yaptıkları çalışmada evlilerin bekarlara göre daha az duygusal yalnızlık yaşadıklarını, bunun dışında sosyal yalnızlık için medeni durumun herhangi bir etkisinin olmadığı sonucuna ulaşmıştır. Şişman ve Turan (2004) yaptıkları araştırmada çalışanların sosyal-duygusal yalnızlıklarına ilişkin bulguları bütün olarak değerlendirildiklerinde çalışanların sosyal-duygusal yalnızlık düzeylerinin pek düşük olmadığı sonucuna ulaşmışlar ve bu sonucu Türk kültünün birey merkezli değil toplumcu bir kültür olmasından dolayı sosyal-duygusal yalnızlık yaşamadıkları şeklinde yorumlamışlardır. Mercan, Oyur, Alamur, Gül ve Bengül'ün (2012) akademik ve idari personel üzerinde yaptıkları araştırmada yalnızlık ölçeğinin alt boyutları olan duygusal yoksunluk ve sosyal arkadaşlığın cinsiyet değişkeni ve medeni duruma göre anlamlı bir farklılık göstermediği sonucuna ulaşmışlardır. Bunun yanısıra duygusal yoksunluğun, yaş ve çalışma süresi arasında anlamlı bir ilişki bulunduğu sonucuna ulaşmışlardır. Yılmaz ve Aslan (2013) öğretmenler üzerinde yaptıkları araştırmada, öğretmenlerin iş yerinde yalnızlıklarının cinsiyet değişkenine göre farklılaşmadığ 1 sonucuna ulaşmışlardır. Medeni duruma göre ise, iş yerinde yalnızlıklarının duygusal yoksunluk boyutlarında anlamlı bir farklılık tespit edilmemiş, sosyal arkadaşlık boyutunda anlamlı bir farklılık tespit edilmiştir. Bekar öğretmenler kendilerini sosyal arkadaşlık boyutunda evli öğretmenlere göre kendilerini daha fazla iş yerinde yalnız hissettikleri sonucuna ulaşmışlardır. Bakioğlu ve Korumaz (2014) yaptıkları araştırmada öğretmenlerin okulda yalnızlık durumlarının kariyer evrelerine göre, öğrenim seviyelerine ve medeni durumları göre anlamlı düzeyde farklılaştığı sonucuna ulaşmışlardır. Yüksel, Özcan ve Kahraman (2013) yaptıkları araştırmada yalnızlığın cinsiyet değişkenine göre incelediklerinde erkek öğretmenlerin bayan öğretmenlere göre daha yalnız olduğu sonucuna ulaşmışlardır. Bunun yanı sıra yaş değişkenlerinin yalnızlık üzerinde etkili olmadığı sonucuna varılmıştır. Yine medeni durumunun yalnızlık düzeyi değişkeni açısından anlamlı bir fark yaratmadığı sonucuna ulaşmışlardır. Yalnızlık puanlarının, 
emeklilik yaşı gelince emekli olup olmamaya dair düşüncesi değişkeninde farkl1lık gösterdiği sonucuna ulaşmışlardır. Bu literatür çerçevesinde kurulan hipotezler şu şekildedir.

H1: Çalışanların, cinsiyet değişkenine göre yalnızlık düzeyleri farklılaşmaktadır.

H2: Çalışanların medeni durum değişkenine göre yalnızlık düzeyleri farklılaşmaktadır.

H3: Çalışanların idarecilik değişkenine göre yalnızlık düzeyleri farklılaşmaktadır.

H4: Çalışanların, yaş değişkenine göre yalnızlık düzeyleri farklılaşmaktadır.

H5: Çalışanların eğitim değişkenine göre yalnızlık düzeyleri farklılaşmaktadır.

H6: Çalışanların mesleki deneyim değişkenine göre yalnızlık düzeyleri farklılaşmaktadır.

\section{Yöntem}

\section{1.Örneklem}

Anketlerin ekonomik bir şekilde ve oldukça büyük örneklemlerden büyük miktarda veri toplanmasına olanak sağlamasından dolayı (Saunders, Lewis ve Thornhill, 2009), bu çalışmada anket kullanılmıştır. Çalışma örneklemini, Türkiye'de Çorum ilinde kamu ve özel olmak üzere hizmet sektöründe çalışan beyaz yakalı çalışanlar oluşturmaktadır. Gönüllülük esasına göre dağıtılan anketlerden hatalı veya eksik doldurulmuş anketler çıkarıldıktan sonra, 211 anket analize tabi tutulmuştur. Açımlayıcı faktör analizi ve doğrulayıcı faktör analizi olmak üzere iki faktör analizi ile ölçeğin analizleri karşıllaştırmalı olarak gerçekleştirilmiştir.

Araştırmada katılımcıların araştırma değişkenlerine ilişkin görüşleri cinsiyete, medeni duruma ve yönetici olup olmadıklarına göre anlamlı farklılık gösterip göstermediğini belirlemek amacıyla bağımsız gruplar için Mann Whitney U-Testi Testi yapılmıştır. Katılımcıların araştırma değişkenlerine ilişkin görüşlerinin yaşlarına, eğitim durumlarına, mesleki deneyimlerine ve ne kadar süredir o işletmede çalıştıklarına göre anlamlı bir farklılık gösterip göstermediğini belirlemek amacıyla Kruskal Wallis H-Testi yapılmıştır.

\section{2. Ölçek Değerlendirme ve Veri Toplama Araçları}

Araştırmada kullanılan anket formu iki bölümden oluşmaktadır. Birinci bölümde katılımcıların demografik değişkenleri hakkında sorular yer almaktadır. Bunlar, cinsiyet, eğitim durumu, medeni durum, yaş, idarecilik ve mesleki deneyimi (yıl olarak) içeren sorulardır. İkinci bölümde işyeri yalnızlı̆̆ ölçeği yer almaktadır.

\subsection{1. Ölçek Değerlendirme}

Araştırmalarda bir değişkenin teorik olarak ele alınmasının ardından araştırmanın ölçeği geliştirilip araştırma süreçlerinde kullanılır. Yalnızlık kavramını değerlendirmek için alanyazında çok sayıda ölçek geliştirildiği görülmektedir. Bunlar, Rubenstein ve Shaver (1982) tarafindan geliştirilen NYU Yalnızlık Ölçeği; DiTommaso ve Spinner (1993) tarafindan geliştirilen Yetişkinler için Sosyal ve Duygusal Yalnızlık Ölçeği (SELSA); Schmidt ve Sermat (1983) tarafından geliştirilen Ayrımsal Yalnızlık Ölçeği ve alanyazında en çok kullanılan Russel ve arkadaşları (1978, 1980a, 1980b, 1984) tarafindan geliştirilen (UCLA- University of California, Los Angeles) Yalnızlık Ölçeği' dir. Yalnızlık kavramının bu ölçeklerle ölçülebilir olması alanyazında kavramın hem teorik hem de uygulamalı olarak yapılan çalışmalarla derinlemesine incelenmesine yarar sağlamıştır denilebilir.

Wright ve arkadaşları tarafindan (2006) UCLA yalnızlık ölçeği, ölçek maddeleri iş yaşamına uygun hale getirilerek alanyazında "Loneliness at Work Scale (LAWS)-İş Yaşamında Yalnızlık Ölçeği” adı altında yer almaya başlamıştır. Alanyazında bu ölçeğin işyeri yalnızlı̆̆ı ile ilgili alanyazında en çok kullanılan ölçek olduğu söylenebilir. Bu çalışmada Wright ve arkadaşları (2006) tarafından geliştirilen işyerinde yalnızlık ölçeğinin geçerliliği ve güvenilirliği üzerinde analizler 
yapılacaktır. Ardından iş yeri yalnızlığının demografik özellikler bağlamında algı farklılıkları incelenecektir.

\subsubsection{Veri Toplama Araçları}

Wright ve arkadaşları (2006) tarafından geliştirilen ölçek "duygusal yoksunluk ve sosyal arkadaşlık" olmak üzere iki boyutta önerilmiştir. Bu ölçekte 16 ifade bulunmaktadır. İlk 9 soru duygusal yalnızlığı, diğerleri sosyal yalnızlığ ${ }^{1}$ ifade etmektedir. Bu ölçekte sorular duygusal yalnızlık için, "İ̧ ortamında baskı altındayken iş arkadaşlarım tarafından yalnız bırakıldığımı hissederim." ve "Kendimi iş arkadaşlarımdan duygusal olarak uzak hissediyorum." şeklindedir. Sosyal yalnızlık için sorular "İ̧ yerinde istediğimde kişisel düşüncelerimi paylaşabileceğim kimse yoktur." ve "İşyerinde mola zamanlarında beraber vakit geçirebileceğim biri vardır (ters)." şeklindedir. Ölçek için 5'li likert tipi derecelendirme kullanılmıştır (1 kesinlikle katılmıyorum, 5 kesinlikle katıllyorum). Ölçeğe farklı kültürlerde geçerlilik ve güvenilirlik analizlerinin çok az yapıldığı tespit edilmiştir (Wright, 2005).

Ölçeğin öncelikle ingilizce'den Türkçe’ye tercümesi yapılmıştır. Anlaşılırlık, açık ifadeler, ortak dil ve kültürel kriterler göz önünde bulundurularak çeviri-değerlendirme ve geri çevirideğerlendirme yapılarak ölçeğin İngilizce'den Türkçe'ye çevirisi yapılmıştır. Bu işlem için akademisyenlerden yardım alınmıştır. Farklılıklar gözden geçirilerek ifadeler iyileştirilmiştir.

\section{Bulgular} edilmektedir.

Ölçeğe ait kısa ifadeler ve faktör yapıları sonuçları Tablo 1'de detaylı olarak ifade

Tablo 1: İşyeri Yalnızlığı Ölçeğinin İki ve Tek Faktörlü Olan Faktör Yapıları ve Faktör Yükleri

\begin{tabular}{|c|c|c|c|c|}
\hline & & $\begin{array}{c}\text { Duygusal } \\
\text { Yalnizlık }\end{array}$ & $\begin{array}{c}\text { Sosyal } \\
\text { Yalnızlık }\end{array}$ & $\begin{array}{c}\text { Tek faktörlü } \\
\text { Yapı }\end{array}$ \\
\hline \multirow{9}{*}{ 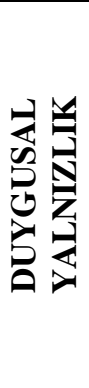 } & D1. Yalnız bırakıldığımı hissederim. & $\mathbf{0 , 7 0 0}$ & & 0,674 \\
\hline & D2. Bana mesafeli durduklarını hissediyorum. & $\mathbf{0 , 8 9 3}$ & & 0,846 \\
\hline & D3. Araya mesafe koyduğumu hissediyorum. & $\mathbf{0 , 8 1 5}$ & & $\mathbf{0 , 7 7 8}$ \\
\hline & D4. Duygusal olarak uzak hissediyorum. & $\mathbf{0 , 8 5 9}$ & & 0,799 \\
\hline & D5. İlişkilerimden memnunum.* & $\mathbf{0 , 6 8 2}$ & & $\mathbf{0 , 7 5 2}$ \\
\hline & D6. Dostluk anlayışı hakimdir. * & $\mathbf{0 , 7 1 4}$ & & $\mathbf{0 , 7 3 8}$ \\
\hline & D7. Kendimi dışlanmış hissediyorum. & $\mathbf{0 , 8 5 6}$ & & $\mathbf{0 , 8 0 2}$ \\
\hline & D8. Aramda bir kopukluk hissederim. & $\mathbf{0 , 8 5 0}$ & & $\mathbf{0 , 7 6 2}$ \\
\hline & D9. Bir boşluk duygusu içinde hissederim. & $\mathbf{0 , 8 5 5}$ & & $\mathbf{0 , 8 0 7}$ \\
\hline \multirow{6}{*}{ 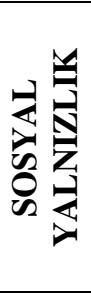 } & S1. Sosyal ilişkilerim vardır. * & & $\mathbf{0 , 7 3 6}$ & $\mathbf{0 , 4 9 8}$ \\
\hline & S3. Günlük sorunlarımı konuşabileceğim biri var. * & & $\mathbf{0 , 7 7 0}$ & $\mathbf{0 , 5 2 3}$ \\
\hline & S4. Kişisel düşüncelerimi paylaşabileceğim kimse yoktur. & & 0,662 & $\mathbf{0 , 4 8 0}$ \\
\hline & $\begin{array}{l}\text { S5. Mola zamanlarında beraber vakit geçirebileceğim biri } \\
\text { vardır. * }\end{array}$ & & $\mathbf{0 , 8 6 9}$ & 0,614 \\
\hline & S6. Arkadaş grubunun bir parçası olarak hissederim. * & & $\mathbf{0 , 8 5 9}$ & $\mathbf{0 , 5 4 7}$ \\
\hline & S7. Beni dinleme zahmetinde bulunan insanlar vardır * & & $\mathbf{0 , 8 1 6}$ & $\mathbf{0 , 5 7 2}$ \\
\hline & - $\quad$ Bu Çalışmada Cronbach alfa iç tutarlılık katsayısı & 0,93 & 0,88 & 0,91 \\
\hline & $\begin{array}{l}\text { - Wright vd.'nin (2006) Çalışmasında Cronbach alfa } \\
\text { iç tutarlılık katsayısı ** }\end{array}$ & 0,93 & 0,87 & 0,80 \\
\hline & - $\quad$ Bu Çalışmada Ortalama-Standart Sapma & \begin{tabular}{|l|l|}
2,37 & 0,88 \\
\end{tabular} & \begin{tabular}{l|l|}
2,29 & 0,84 \\
\end{tabular} & 0,72 \\
\hline
\end{tabular}

\footnotetext{
${ }^{1}$ Wright ve arkadaşları ölçeğin boyutlarını duygusal yoksunluk ve sosyal arkadaşlık olarak ifade etmişlerdir. Bu çalışmada bu boyutlar "duygusal yalnızlık ve sosyal yalnızlık" olarak ifade edilmektedir. Çünkü boyutlar için belirlenen bu ifadeler boyutların içeriği ile bir anlam bütünlüğü içerisindedir. Duygusal yalnızlık ve sosyal yalnızlık” toplam ölçek içinde bir anlam bütünlüğü ifade ettiği düşünülmektedir. Bu sebeplerden dolayı boyutlar bu şekilde ifade edilmiştir.
} 
*Maddeler Kısaltılarak Verilmiştir, İşaretli Olanlar Ters Maddelerdir.

**Bu aşamada Wright ve arkadaşları (2006) tarafından geliştirilmiş olan işyeri yalnızlığı ölçeği hem bu çalışmada hem de orijinal ölçekte tespit edilen istatistiksel sonuçlar karşılaştırmalı olarak verilecektir.

Wright ve arkadaşlarının (2006) iki boyutlu ölçeğinde açımlayıcı faktör analizi sonucuna göre birinci faktör $\% 53,44$, ikinci faktör $\% 8,37$ oranında varyansı açıkladığ 1 tespit edilmiştir. Evigenvalues değeri birinci faktör 8,55 ve ikinci faktör için 1,34 olarak tespit edilmiştir.

Bu çalışmada ölçeğin iki boyutlu açımlayıcı faktör analizi SPSS programında yapılmıştır. Faktör çıkarma yöntemi olarak Temel Bileşenler Analizi (Principal Components Analysis-PCA), rotasyon yöntemi olarak Varimax yöntemi uygulanmıştır. Öncelikle maddelerin ortak faktör varyansları hesaplanmıştır. Sosyal yalnızlık ölçeğinin 2. maddesinin duygusal yalnızlık faktöründe görüldüğ̈ ve maddenin hesaplanan ortak varyansının 0,37 olduğu tespit edilmiştir. Diğer maddelerin kendi faktörleri içerisinde toplandığı ve ortak faktör varyanslarının 0,46 ve üzeri değerler aldığı tespit edilmiştir. Bu nedenlerden dolayı sosyal yalnızlık faktörünün 2. maddesi çıkartılarak analize devam edilmiştir. Faktör yüklerinin son hali yukarıda Tablo 1'de gösterilmektedir.

İfade çıkartıldıktan sonra analize devam edilmiştir. Döndürme işleminden sonra birinci faktör \%39,976, ikinci faktör \%26,868 oranında varyansı açıkladığı belirlenmiştir. Bu iki boyutun varyansa yaptığı katkı \%66,843'tür. Her bir faktörün toplam varyansa yapmış olduğu katkı ise, $\% 47,692$ 'dir. Kaiser-Meyer-Olkin (KMO) örneklem yeterlilik değerinin 0,88 olduğu ve örneklemin büyüklüğünün faktör analizi için yeterli olduğu tespit edilmiştir. Bartlett küresellik testinin anlamlı olması $\left(\mathrm{x}^{2}(105)=2594,783, \mathrm{p}<0,0001\right)$ maddeler arasındaki korelasyon ilişkilerinin faktör analizi için uygun olduğuna işaret etmektedir. Evigenvalues değeri birinci faktör 7,15 ve ikinci faktör için 2,87 olarak tespit edilmiştir.

Ölçeğin tek boyutlu açımlayıcı faktör analizinde, faktör çıkarma yöntemi olarak Temel Bileşenler Analizi (Principal Components Analysis-PCA), rotasyon yöntemi olarak Varimax yöntemi uygulanmıştır. Döndürme işleminden sonra tek boyutun varyansa yaptığ 1 katkı \% 47,692' dir. Kaiser-Meyer-Olkin (KMO) örneklem yeterlilik değeri ve Bartlett küresellik testinin sonucu yukarıda iki faktörlü analizde ifade edilen değerlerin aynısıdır. Açımlayıcı faktör analizinin ardından ölçeğe AMOS programında hem iki faktörlü hem de tek faktörlü Doğrulayıcı Faktör Analizi (DFA) yapılmış. Analiz sonucunda ortaya çıkan uyum iyiliği değerleri Wright ve arkadaşları (2006) tarafindan yapılan DFA analizi ile karşılaştırmalı olarak verilmiştir.

Tablo 2: İşyeri Yalnızlığı Ölçeğinin Orijinal Ölçekle Karşılaştırmalı Olarak Tek ve İki Faktörlü Uyum İyiliği Değerleri

\begin{tabular}{|c|c|c|c|c|c|c|}
\hline & Kikare / sd & NFI & CFI & GFI & AGFI & RMSEA \\
\hline 1.İki Faktörlü Yapı* & $105,852 / 70=1,512$ & .96 & .98 & .95 & .89 & .04 \\
\hline 2.Tek Faktörlü Yapı* & $66,085 / 56=1,180$ & .97 & .99 & .96 & .91 & .02 \\
\hline $\begin{array}{l}\text { 3.Wrigh ve arkadaşlarının } \\
\text { (2006) İki Faktörlü Yapısı }\end{array}$ & $683,9 / 104=6,57$ & - & .93 & .87 & .83 & .09 \\
\hline $\begin{array}{l}\text { 4.Wrigh ve arkadaşlarının } \\
\text { (2006) Tek Faktörlü Yapısı }\end{array}$ & $385,5 / 103=3,74$ & - & .85 & .75 & .67 & .12 \\
\hline 5.İyi Uyum** & $\leq 5$ & $\geq .90$ & $\geq .90$ & $\geq .85$ & $\geq .90$ & $\leq .10$ \\
\hline 6.Mükemmel Uyum** & $\leq 2$ & $\geq .95$ & $\geq .95$ & $\geq .90$ & $\geq .1$ & $\leq .05$ \\
\hline
\end{tabular}

*Bu çalışmanın uyum iyiliği sonuçları, **Kaynak: Çokluk, vd., 2010.

Tablo 2'de görüldüğü gibi hem iki boyutlu hem de tek boyutlu ele alınan işyeri yalnızlığ ölçeğinin uyum iyiliği değerlerinin belirlenen referans aralığında olduğu görülmektedir. Hatta değerler karşılaştırıldığında tek faktörlü yapının uyum iyiliği değerlerinin iki boyutlu yapıdan biraz daha iyi olduğu tespit edilmiştir. Tablo 2'de Wright ve arkadaşlarının (2006) hem iki faktörlü hem de tek faktörlü yapmış oldukları DFA sonuçlarına da yer verilmiştir. İki boyutlu yapının duygusal 
yalnızlık boyutunun DFA' ada regresyon katsayıları .93 ve .67 arasında değişmektedir. Sosyal yalnızlık boyutunun DFA'ada regresyon katsayıları .94 ve .52 arasında değişmektedir. Tek boyutlu yapının regresyon katsayıları ise .93 ve .30 arasında değişmektedir. Yapılan analizlerin ardından alanyazında bu ölçeği kullanan çalışmaların ölçeği tek faktörle mi yoksa iki faktörle mi kullandıkları Tablo 3'te belirtilmiştir.

Tablo 3: İşyeri Yalnızlığı Ölçeğini Kullanan Diğer Araştırmaların Raporları

\begin{tabular}{|l|c|c|c|l|c|c|}
\hline \multicolumn{1}{|c|}{ Yazar } & $\begin{array}{c}\text { İki Boyut/Tek } \\
\text { Boyut }\end{array}$ & Madde & $\begin{array}{c}\text { Örneklem } \\
\text { büyüklüğ̈̈(N) }\end{array}$ & \multicolumn{1}{|c|}{ Örneklem } & $\begin{array}{c}\text { Cronbach } \\
\text { Alfa }\end{array}$ & Y l \\
\hline Öge, Çetin ve Top & Tek boyut & 16 & 130 & DHMI* & .91 & 2018 \\
\hline $\begin{array}{l}\text { Peng, Chen, Xia ve } \\
\text { Ran }\end{array}$ & Tek boyut & 16 & 261 & $\begin{array}{l}\text { Çin'de kamu ve özel } \\
\text { işletmelerde çalışanlar }\end{array}$ & .87 & 2017 \\
\hline $\begin{array}{l}\text { Chen, Wen, Peng } \\
\text { ve Liu }\end{array}$ & Tek boyut & 16 & 232 & Çin'de özel şirket & .81 & 2016 \\
\hline $\begin{array}{l}\text { Karakaya, } \\
\text { Büyükyllmaz ve Ay }\end{array}$ & İki Boyut & $14^{* *}$ & 413 & Kardemir A.Ş. & 96 & 2015 \\
\hline $\begin{array}{l}\text { Tabancalı ve } \\
\text { Korumaz }\end{array}$ & İki Boyut & 16 & 123 & İl Ĕğitim Denetmenleri & .91 & 2014 \\
\hline Yılmaz ve Aslan & İki Boyut & 16 & 402 & $\begin{array}{l}\text { İlköğretim okulu } \\
\text { öğretmeni }\end{array}$ & .93 & 2013 \\
\hline
\end{tabular}

*DHMI-Devlet hava meydanları genel işletmesi

**Araştırmacılar tarafindan yapılan analiz sonucunda, D5 ve D7 ifadeleri faktör yapılarını ve uyum iyiliklerini olumsuz etkilediği için analizden çıkartılmıştır.

Tablo 3'teki rapora göre farklı kültürler ve farklı örneklemler üzerinde işyeri yalnızlı̆̆ ölçeğinin hem iki boyutu ile hem de tek boyutu ile kullanıldığı görülmektedir. Yapılan analizler ve alanyazından elde edilen rapora göre ölçek her iki açıdan istatistiksel olarak kullanıma uygundur denilebilir.

Tablo 3'te görüldüğü gibi işyeri yalnızlığı ölçeği hem tek boyutta hem de duygusal yalnızlık ve sosyal yalnızlık olmak üzere iki boyutta ölçülmektedir. Bu çalışmada tek boyut üzerinen ve iki boyutlu hali ile demografik değişkenler arasında anlamlı bir farklılık olup olmadığı incelenmiştir. Aşağıdaki tablolarda bu farklılıklar ortaya konmuştur.

Çalışmada, Bağımsız Örneklemler T Testi yerine, analizlerde puanların dağılımı normallik varsayımını karşılamadığı için, bu durumda sıklıkla kullanılan Mann Whitney U-Testi (Büyüköztürk, 2014: 166) tercih edildi. İlişkisiz Örneklemler için Tek Faktörlü Varyans Analizi (One-Way Anova) yerine Kruskal Wallis H-Testi kullanılmıştır. Bu test, "puanların grup değişkenine göre oluşturulan her bir alt (örneklemde) normal dağılm ve varyanslarının eşitliği” varsayımlarını gerektirmediği için tek yönlü varyans analizine alternatif bir tekniktir. Araştırmada puanların normallik varsayımını karşılamaması sebebiyle Kruskal Wallis H-Testi (Büyüköztürk, 2014: 168) tercih edildi. Bu işlem, parametrik bir test olan tek yönlü ANOVA'nın normallik varsayımının karşılnmadığı durumlarda önerilmektedir (Büyüköztürk, 2014: 169).

Tablo 4: İşyeri Yalnızlığı Algısının Cinsiyete Göre Mann Whitney U-Testi Sonucu

\begin{tabular}{|c|c|c|c|c|c|c|c|}
\hline & Cinsiyet & Sayı & Sira Ort. & Sira Toplamı & $\mathbf{Z}$ & $\mathbf{U}$ & $\mathbf{P}$ \\
\hline \multirow{2}{*}{$\begin{array}{c}\text { Toplam } \\
\text { Yalnızlık }\end{array}$} & Kadın & 85 & 105,60 & 8976,00 & \multirow[t]{2}{*}{$-0,078$} & \multirow[t]{2}{*}{5321,000} & \multirow[t]{2}{*}{,938 } \\
\hline & Erkek & 126 & 106,27 & 13390,00 & & & \\
\hline \multirow{2}{*}{$\begin{array}{l}\text { Duygusal } \\
\text { Yalnızlık }\end{array}$} & Kadın & 85 & 108,02 & 9181,50 & \multirow{2}{*}{$-0,397$} & \multirow[t]{2}{*}{5183,500} & \multirow[t]{2}{*}{,691 } \\
\hline & Erkek & 126 & 104,64 & 13184,50 & & & \\
\hline \multirow{2}{*}{$\begin{array}{c}\text { Sosyal } \\
\text { Yalnızlık }\end{array}$} & Kadın & 85 & 99,72 & 8476,50 & \multirow[t]{2}{*}{$-1,242$} & \multirow[t]{2}{*}{4821,500} & \multirow[t]{2}{*}{,214 } \\
\hline & Erkek & 126 & 110,23 & 13889,50 & & & \\
\hline
\end{tabular}


Çalışanların cinsiyetlerine göre yalnızlık ölçeğinden aldıkları puanların Mann Whitney UTesti sonuçları Tablo 4'te verilmiştir. Buna göre bu örneklem üzerinde işyeri yalnızlığı ile cinsiyet arasında anlamlı bir fark bulunanamamıştır. Bu sonuca göre $\mathrm{H} 1$ hipotezi reddedilmiştir.

Tablo 5: İşyeri Yalnızlığı Algısının Medeni Duruma Göre Mann Whitney U-Testi Sonucu

\begin{tabular}{|c|c|c|c|c|c|c|c|}
\hline & $\begin{array}{l}\text { Medeni } \\
\text { Durum }\end{array}$ & Sayı & Sira Ort. & Sira Toplamı & $\mathbf{Z}$ & $\mathbf{U}$ & $\mathbf{P}$ \\
\hline \multirow{2}{*}{$\begin{array}{c}\text { Toplam } \\
\text { Yalnızlık }\end{array}$} & Evli & 144 & 105,19 & 15147,50 & \multirow[t]{2}{*}{,- 282} & \multirow[t]{2}{*}{4707,500} & \multirow[t]{2}{*}{,778 } \\
\hline & Bekar & 67 & 107,74 & 7218,50 & & & \\
\hline \multirow{2}{*}{$\begin{array}{l}\text { Duygusal } \\
\text { Yalnızlık }\end{array}$} & Evli & 144 & 105,55 & 15198,50 & \multirow[t]{2}{*}{,- 160} & \multirow[t]{2}{*}{4758,500} & \multirow[t]{2}{*}{873} \\
\hline & Bekar & 67 & 106,98 & 7167,50 & & & \\
\hline \multirow{2}{*}{$\begin{array}{c}\text { Sosyal } \\
\text { Yalnızlık }\end{array}$} & Evli & 144 & 104,91 & 15107,00 & \multirow[t]{2}{*}{,- 385} & \multirow[t]{2}{*}{4667,000} & \multirow[t]{2}{*}{,700 } \\
\hline & Bekar & 67 & 108,34 & 7259,00 & & & \\
\hline
\end{tabular}

Çalışanların medeni durumlarına göre yalnızlık ölçeğinden aldıkları puanların Mann Whitney U-Testi sonuçları Tablo 5'te verilmiştir. Buna göre bu örneklem üzerinde işyeri yalnızlı̆ 1 ile çalışanların medeni durumları arasında anlamlı bir fark bulunanamamıştır. Bu sonuca göre $\mathrm{H} 2$ hipotezi reddedilmiştir.

Tablo 6: İşyeri Yalnızlığı Algısının İdareci Olup Olmadıklarına Göre Mann Whitney U-Testi

\begin{tabular}{|c|c|c|c|c|c|c|c|}
\hline \multicolumn{8}{|c|}{ Sonucu } \\
\hline & İdarecilik & Sayı & Sira Ort. & $\begin{array}{c}\text { Sira } \\
\text { Toplamı }\end{array}$ & $\mathbf{Z}$ & $\mathbf{U}$ & $\mathbf{P}$ \\
\hline \multirow[t]{2}{*}{$\begin{array}{c}\text { Toplam } \\
\text { Yalnızlık }\end{array}$} & $\begin{array}{c}\text { İdarecilik } \\
\text { Var }\end{array}$ & 62 & 111,48 & 6911,50 &,- 841 & 4279,500 & ,400 \\
\hline & $\begin{array}{c}\text { İdarecilik } \\
\text { Yok }\end{array}$ & 149 & 103,72 & 15454,50 & & & \\
\hline \multirow[t]{2}{*}{$\begin{array}{l}\text { Duygusal } \\
\text { Yalnızlık }\end{array}$} & $\begin{array}{c}\text { İdarecilik } \\
\text { Var }\end{array}$ & 62 & 106,64 & 6611,50 &,- 098 & 4579,500 & 922 \\
\hline & $\begin{array}{c}\text { İdarecilik } \\
\text { Yok }\end{array}$ & 149 & 105,73 & 15754,50 & & & \\
\hline \multirow[t]{2}{*}{$\begin{array}{c}\text { Sosyal } \\
\text { Yalnızlık }\end{array}$} & $\begin{array}{c}\text { İdarecilik } \\
\text { Var }\end{array}$ & 62 & 117,60 & 7291,00 & $-1,802$ & 3900,000 &, 072 \\
\hline & $\begin{array}{l}\text { İdarecilik } \\
\text { Yok }\end{array}$ & 149 & 101,17 & 15075,00 & & & \\
\hline
\end{tabular}

Çalışanların idareci olup olmadıklarına göre yalnızlık ölçeğinden aldıkları puanların Mann Whitney U-Testi sonuçları Tablo 6'da verilmiştir. Buna göre bu örneklem üzerinde işyeri yalnızlı̆̆ 1 ile çalışanların idarecilik durumları arasında anlamlı bir fark bulunanamamıştır. Bu sonuca göre H3 hipotezi reddedilmiştir. 
Tablo 7: İşyeri Yalnızlığı Algısının Yaş Gruplarına Yönelik Kruskal Wallis H-Testi Sonuçları

\begin{tabular}{|c|c|c|c|c|c|c|}
\hline & Yaş & Sayı & Sira Ort. & $\begin{array}{l}\text { Chi- } \\
\text { square }\end{array}$ & S.D. & $\mathbf{P}$ \\
\hline \multirow{4}{*}{$\begin{array}{l}\text { Toplam } \\
\text { Yalnızlık }\end{array}$} & $18-27$ & 29 & 104,02 &, 103 & 3 & ,991 \\
\hline & $28-37$ & 98 & 105,35 & & & \\
\hline & $38-47$ & 76 & 107,19 & & & \\
\hline & $48-59$ & 8 & 109,88 & & & \\
\hline \multirow{4}{*}{$\begin{array}{l}\text { Duygusal } \\
\text { Yalnızlık }\end{array}$} & $18-27$ & 29 & 105,26 & 136 & 3 & ,987 \\
\hline & $28-37$ & 98 & 107,60 & & & \\
\hline & $38-47$ & 76 & 104,51 & & & \\
\hline & $48-59$ & 8 & 103,19 & & & \\
\hline \multirow{4}{*}{$\begin{array}{c}\text { Sosyal } \\
\text { Yalnızlık }\end{array}$} & $18-27$ & 29 & 95,55 & 1,412 & 3 & ,703 \\
\hline & $28-37$ & 98 & 105,83 & & & \\
\hline & $38-47$ & 76 & 108,84 & & & \\
\hline & $48-59$ & 8 & 119,00 & & & \\
\hline
\end{tabular}

Çalışanların yaş gruplarına göre yalnızlık ölçeğinden aldıkları puanların Kruskal Wallis HTesti sonuçları Tablo 7'de verilmiştir. Analiz sonuçları, belli yaş gruplarındaki çalışanların yalnızlık ölçeğinden aldıkları puanların, yaş gruplarına göre anlamlı bir farklılaşma olmadığını göstermektedir. Bu sonuca göre $\mathrm{H} 4$ hipotezi reddedilmiştir.

Tablo 8: İşyeri Yalnızlı̆̆ı Algısının Eğitim Düzeylerine Yönelik Kruskal Wallis H-Testi Sonuçları

\begin{tabular}{|c|c|c|c|c|c|c|}
\hline & Eğitim & Sayı & Sira Ort. & $\begin{array}{c}\text { Chi- } \\
\text { square }\end{array}$ & S.D. & $\mathbf{P}$ \\
\hline \multirow{5}{*}{$\begin{array}{c}\text { Toplam } \\
\text { Yalnızlık }\end{array}$} & Lise & 35 & 102,77 & 3,829 & 4 & ,430 \\
\hline & Önlisans & 38 & 99,71 & & & \\
\hline & Lisans & 89 & 113,12 & & & \\
\hline & Y. Lisans & 39 & 105,96 & & & \\
\hline & Diğer & 10 & 77,95 & & & \\
\hline \multirow{5}{*}{$\begin{array}{l}\text { Duygusal } \\
\text { Yalnızlık }\end{array}$} & Lise & 35 & 104,90 & 5,146 & 4 & ,273 \\
\hline & Önlisans & 38 & 101,76 & & & \\
\hline & Lisans & 89 & 114,15 & & & \\
\hline & Y. Lisans & 39 & 101,15 & & & \\
\hline & Diğer & 10 & 72,30 & & & \\
\hline \multirow[t]{5}{*}{ Sosyal Yalnızlık } & Lise & 35 & 98,29 & 1,277 & 4 & ,865 \\
\hline & Önlisans & 38 & 103,25 & & & \\
\hline & Lisans & 89 & 107,84 & & & \\
\hline & Y. Lisans & 39 & 112,67 & & & \\
\hline & Diğger & 10 & 101,10 & & & \\
\hline
\end{tabular}

Çalışanların eğitim düzeylerine göre yalnızlık ölçeğinden aldıkları puanların Kruskal Wallis H-Testi sonuçları Tablo 8'de verilmiştir. Analiz sonuçları, belli eğitim düzeyindeki çalışanların yalnızlık ölçeğinden aldıkları puanların, eğitim düzeylerine göre anlamlı bir farklılaşma olmadığını göstermektedir. Bu sonuca göre $\mathrm{H} 5$ hipotezi reddedilmiştir. 
Tablo 9: İşyeri Yalnızlığı Algısının Mesleki Deneyim Yılına Yönelik Kruskal Wallis H-Testi Sonuçlar1

\begin{tabular}{|c|c|c|c|c|c|c|}
\hline & $\begin{array}{c}\text { Mesleki } \\
\text { Deneyim }\end{array}$ & Sayı & Sura Ort. & Chi-square & S.D. & $\mathbf{P}$ \\
\hline \multirow{4}{*}{$\begin{array}{c}\text { Toplam } \\
\text { Yalnızlık }\end{array}$} & $0-5$ Yil & 54 & 94,83 & \multirow[t]{4}{*}{5,315} & \multirow[t]{4}{*}{3} & \multirow[t]{4}{*}{, 150} \\
\hline & 6-10 Y1l & 76 & 101,61 & & & \\
\hline & $11-15$ Yil & 51 & 115,25 & & & \\
\hline & 16 ve üzeri & 30 & 121,52 & & & \\
\hline \multirow{4}{*}{$\begin{array}{l}\text { Duygusal } \\
\text { Yalnızlık }\end{array}$} & $0-5$ Y1l & 54 & 94,64 & \multirow[t]{4}{*}{4,100} & \multirow[t]{4}{*}{3} & \multirow[t]{4}{*}{,25 } \\
\hline & 6-10 Y1l & 76 & 103,74 & & & \\
\hline & 11-15 Yil & 51 & 116,51 & & & \\
\hline & 16 ve üzeri & 30 & 114,32 & & & \\
\hline \multirow{4}{*}{$\begin{array}{c}\text { Sosyal } \\
\text { Yalnızlık }\end{array}$} & $0-5$ Yil & 54 & 95,57 & \multirow[t]{4}{*}{5,019} & \multirow[t]{4}{*}{3} & \multirow[t]{4}{*}{, 170} \\
\hline & 6-10 Y11 & 76 & 103,47 & & & \\
\hline & $11-15 \mathrm{Y} 11$ & 51 & 109,39 & & & \\
\hline & 16 ve üzeri & 30 & 125,42 & & & \\
\hline
\end{tabular}

Çalışanların mesleki deneyim yılına göre yalnızlık ölçeğinden aldıkları puanların Kruskal Wallis H-Testi sonuçları Tablo 9'da verilmiştir. Analiz sonuçları, belli mesleki deneyim yılındaki çalışanların yalnızlık ölçeğinden aldıkları puanların, mesleki deneyim yıllarına göre anlamlı bir farklılaşma olmadığını göstermektedir. Bu sonuca göre H6 hipotezi reddedilmiştir. Genel olarak değerlendirdiğimizde, hizmet sektörü işlemlerinin çoğu iletişim gerektirmektedir. $\mathrm{Bu}$ iletişim sürecinde çalışanların sürekli birileri ile iletişim halinde olmaları onların işyeri yalnızlığı duygusu hissetmemelerine neden olmaktadır, şeklinde ifade edilebilir. Nitekim hizmet sektörü işletmeler, kişiler, tüketiciler, müşteriler arasında gerçekleşen işlemlerin çoğunu yerine getirmektedir. Bu süreç o işletmede bütün çalışanların medeni durumu, yaşı, cinsiyeti ne olursa olsun sürekli birileri ile haberleşme, iletişim kurmalarına neden olmaktadır. Bu durum bu sektörde çalışanların kendilerini işyerinde yalnız hissetmemelerine neden olabilmektedir.

\section{Sonuç}

İşyeri yalnızlığı ölçeğinin geçerlilik ve güvenilirliğini analiz etmek amaciyla Song ve arkadaşlarının (2009), Yang'ın (2003) ve Mbassana'nın (2014) geçerlilik ve güvenilirlik metodolojisi örnek alınmıştır. İşyeri Yalnızlığı ölçeği Wright ve arkadaşları (2006) tarafından geliştirilen "duygusal yoksunluk ve sosyal arkadaşlik" olmak üzere iki boyutta ve 16 ifade olarak önerilmiştir. Araştırmanın örneklemini hizmet sektöründe çalışan 211 beyaz yakalı personel oluşturmaktadır. Bu çalışmada duygusal yoksunluk duygusal yalnızlık olarak, sosyal arkadaşlık ise sosyal yalnızlık olarak ifade edilmiştir.

Araştırmada öncelikle yapılan açımlayıcı faktör analizi sonucunda, maddelerin ortak faktör varyansları hesaplanmıştır. Sosyal yalnızlık boyutunun 2. maddesinin duygusal yalnızlık faktöründe görüldüğü ve maddenin hesaplanan ortak varyansının 0,37 olduğu tespit edilmiştir. Diğer maddelerin kendi faktörleri içerisinde toplandığı ve ortak faktör varyanslarının 0,46 ve üzeri değerler aldığı tespit edilmiştir. Bu nedenlerden dolayı sosyal yalnızlık faktörünün 2. maddesi çıkartılarak analize devam edilmiştir. Sonuç olarak ölçeğe 15 madde ile geçerlilik ve güvenilirlik analizi yapılmıştır. Analizler sonucunda işyeri yalnızlı̆̆ ölçeğinin hem iki boyutta hem de tek boyutta geçerlemesi gerçekleştirilmiş ve her iki analiz sonucunda da uyum iyiliği değerleri iyi uyum sağladığı belirlenmiştir.

Araştırma demografik değişkenlerden cinsiyet, medeni durum ve yönetici olup olmadıklarına göre anlamlı farklılık gösterip göstermediğini belirlemek amacıyla yapılan Mann Whitney U-Testi sonuçlarına göre, işyeri yalnızlığı ile aralarında anlamlı bir faklılık tespit 
edilememiştir. Katılımcıların yaşlarına, eğitim durumlarına ve mesleki deneyimlerine göre anlamlı bir farklılık gösterip göstermediğini belirlemek amacıyla yapılan Kruskal Wallis H-Testi sonuçları da işyeri yalnızlığı ile aralarında aralarında anlamlı bir fark olmadığını göstermiştir. Çıkan sonuçlara göre H1, H2, H3, H4, H5 ve H6 hipotezleri reddedilmiştir. Yapılan bazı çalışmalarda çıkan sonuçları desteklemektedir. Stroebe vd. (1996) yaptıkları çalışmada sosyal yalnızlık için medeni durumun herhangi bir etkisinin olmadığı sonucuna ulaşmıştır. Mercan vd. (2012) akademik ve idari personel üzerinde yaptıkları araştırmada duygusal yoksunluk ve sosyal arkadaşlı̆̆ın cinsiyet değişkeni ve medeni duruma göre anlamlı bir farklılık göstermediği sonucuna ulaşmışlardır. Yılmaz ve Aslan (2013) öğretmenler üzerinde yaptıkları araştırmada, öğretmenlerin iş yerinde yalnızlıklarının cinsiyet değiş̧enine göre farklılaşmadığı sonucuna ulaşmışlardır. Medeni duruma göre ise duygusal yoksunluk boyutunda anlamlı bir farklılık tespit edilmemiştir. Yüksel vd. (2013) yaptıkları araştırmada yaş değişkenlerinin yalnızlık üzerinde etkili olmadığını tespit etmişlerdir. Yine medeni durumunun yalnızlık düzeyi değişkeni açısından anlamlı bir fark yaratmadığı sonucuna ulaşmışlardır.

Fark analizleri neticesinde çıkan sonuçlara göre hizmet sektörü çalışanlarının demografik değişenlere göre işyeri yalnızlığı ile aralarında fark bulunmaması, bu çalışanların genelde kapalı kapılar ardında değil aksine sürekli müşterilerle yüzyüze iletişim içerisinde olmaları onların işyeri yalnızlığı yaşamadıkları, bu duyguyu hissetmedikleri şeklinde yorumlanabilir.

$\mathrm{Bu}$ çalışmanın kısıtı verilerin tek sektörden ve tek ilden toplanmış olmasıdır. Bu kısıt nedeniyle çıkan sonuçlarla ilgili bir genelleme yapmak mümkün değildir. Çalışmanın farklı illerde ve farklı sektörlerde yapılması sonuçların karşılaştırılarak yorumlanmasına imkan verebilir.

\section{KAYNAKÇA}

Akçit, V. \& Barutçu, E. (2017). The relationship between performance and loneliness at workplace: a study on academicians. European Scientific Journal, 13(10), 235-243.

Amarat, M.; Akbolat, M.; Ünal, Özgün K. \& Bilge, G. (2018). The mediating role of work alienation in the effect of workplace loneliness on nurses' performance. J Nurs Manag., 1-7.

Asher, S.R. \& Paguette, J.A. (2003). Loneliness and peer relations in childhood. Current Directions in Psychological Science, 12 (3), 75-78.

Aşık, N., A. (2016). İş yerinde yalnızlı̆̆ın tükenmişlik üzerine etkisi. Business \& Management Studies: An International Journal, 4(3), 366-384.

Bakioğlu, A. \& Korumaz, M. (2014). Öğretmenlerin okulda yalnızlıklarının kariyer evrelerine göre incelenmesi. Eğitim Bilimleri Dergisi, 39, 25-54.

Bowlby, J. (1969). Attachment and loss. London: Hogarth Press.

Büyüköztürk, Ş. (2014). Sosyal Bilimler İçin Veri Analizi El Kitabl, İstatistik, Araştırma Deseni SPSS Uygulamalart ve Yorum, (20. Baskı), Ankara: Pegem Akademi.

Carr, M. \& Schellenbach, C. (1993). Reflective monitoring in lonely adolescents. Adolescence, 28(111), 737- 745 .

Cindiloğlu, M., Polatcı, S., Özçalık, F. \& Gültekin, Z. (2017). İşyeri yalnızlı̆̆ının iş ve yaşam tatminine etkisi: lider-üye etkileşiminin aracılık rolü. Ege Akademik Bakış, 17(2), 191-200.

Creecy, R.F., Berg W. E., \& Wright, R. (1985). Loneliness among the elderly: a causal approach. Journal Of Gerontology, 40(4), 487-493. 
Coşan, D. (2014). An Evaluation of Loneliness. European Proceedings of Social \& Behavioural Sciences eISSN: 2357-1330, 103-110.

Chen, Y.; Wen, Z.; Peng, J. \& Liu, X. (2016). Leader-follower congruence in loneliness, 1mx and turnover intention. Journal Of Managerial Psychology, 31(4), 864 - 879.

Cüceloğlu, D. (2017). İnsan ve davranışl, psikolojinin temel kavramları. İstanbul: Remzi Kitabevi.

Cramer, M. K.; Ofosu, H. H. \& Barry, E. J. (2000). An abbreviated form of the social and emotional loneliness scale for adults (SELSA). Personality and Individual Differences, 28, 1125-1131.

Demirbaş, B. \& Haşit, G. (2016). İşyerinde yalnızlık ve işten ayrılam niyetine etkisi: akademisyenler üzerine bir uygulama. Anadolu Üniversitesi Sosyal Bilimler Dergisi, 16(2), 137-158.

Ditommaso, E., \& Spinner, B. (1993). The development and initial validation of the social and emotional loneliness scale for adults (SELSA). Personality And Individual Differences, 14(1), 127-134.

Erdil, O. \& Ertosun, Ö. G. (2011), The relationship between social climate and loneliness in the workplace and effects on employee well-being, Procedia Social and Behavioral Sciences 24, 505-525.

Çakır, V. \& Çakır, V. (2011), Yalnızlık ve televizyon kullanımı. Selçuk İletişim, 7(1), 131-147.

Çokluk, Ö.; Şekercioğlu, G. \& Büyüköztürk, Ş. (2014). Sosyal bilimler için çok değişkenli istatistik spss ve lisrel uygulamalart. Ankara: Pegem Akademi.

Ernst, J.M. \& Cacioppo, J.T. (1999). Lonely hearts: psychological perspectives on loneliness. Applied \& Preventive Psychology, 8, 1-22.

Fromm-Reichmann, F. (1959). Loneliness. Psychiatry, 22, 1-15.

Gürbüz, S. \& Şahin, F. (2015). Sosyal bilimlerde araştırma yöntemleri. 2. Bask1, Ankara: Seçkin Yayıncilik.

Holmen, K., Kjerstin E., Andersson L., \& Winblad B. (1992). Loneliness among elderly people living in stockholm: a population study. Journal of Advanced Nursing, 17, 43-51.

Izgar, H. (2009). An investigation of depression and loneliness among school principals. Educational Sciences: Theory and Practice, 9(1), 247-258.

Karakaya, A.; Büyükyılmaz, O. ve Ay, F. (2015), İşyeri yalnızlığının işkoliklik üzerindeki etkisi: Kardemir A.Ş.' 'de bir araştırma, Yönetim Ve Ekonomi Araştırmaları Dergisi, 13(3), 79-100.

Kaymaz, K.; Eroğlu, U. \& Sayılar, Y. (2014), Effect of loneliness at work on the employees' intention to leave, "İ̧, Güç" Endüstri Illişsileri ve İnsan Kaynakları Dergisi, 16(1), 38-53.

Khorshıd, L., Eşer, İ., Zaybak, A., Yapucu, Ü., Arslan, G. G., \& Çınar, Ş. (2004). Huzurevinde kalan yaşlıların yalnızlık düzeylerinin incelenmesi. Türk Geriatri Dergisi, 7(1), 45-50.

Lam, W. L. \& Lau, C.D. (2012), Feeling lonely at work: investigating the consuquences of unsatisfactory workplace relationships, The International Journal Of Human Resource Management, 23(20), 4265-4282.

Mbassana, M. E. (2014), Validating The Dimensions Of The Learning Organization Questionnaire (Dloq) In The Rwandan Context, European Journal of Business, Economics And Accountancy, 2(2), 15-26. 
Mercan, N., Oyur, E., Alamur, B., Gül, S. \& Bengül S. (2012). İş yeri yalnızlı̆̆ı ve sosyal fobi arasındaki ilişkiye yönelik bir araştırma. Organizasyon ve Yönetim Bilimleri Dergisi, 4(1), 213-226.

Moustakas, C. (1961). Loneliness. Englewood Cliffs, NJ: Prentice-Hall.

Öge, E.; Çetin, M. \& Top, S. (2018), The effects of paternalistic leadership on workplace loneliness, work family conflict and work engagement among air traffic controllers in turkey. Journal Of Air Transport Management, 66, 25-35.

Peplau, L. \& Perlman, D. (1982). Loneliness: A sourcebook of current theory, research and therapy. NY: WileyInterscience.

Peng, J.; Chen, Y.; Xia, Y. \& Ran, Y. (2017). Workplace loneliness, leader-member exchange and creativity: the cross-level moderating role of leader compassion. Personality And Individual Differences 104, 510-515.

Rogers, C. (1961). On encounter groups. New York: Harper and Row.

Rokach, A. \& Brock, H. (1998). Coping with loneliness. The Journal of Psychology, 132(1), 107121.

Rubenstein, C. M., \& Shaver, P. (1982). The experience of loneliness. In L. A. Peplau \& D. Perlman, (Eds.), Loneliness: A sourcebook of current theory, research and therapy, (206-223). New York: Wiley-Interscience.

Russel, D., Peplau, L. A., \& Cutrona, C. E. (1980a). The revised ucla loneliness scale: concurrent and discriminate validity evidence. Journal Ofpersonalityand Social Psychology, 39(3), 472480 .

Russell, D., Peplau, L. A., \& Ferguson, M. L. (1978). Developing a measure of loneliness. Journal Of Personality Assessment, 42(3), 290-294.

Russell, D., Peplau, A. \& Cutrano, C. (1980b). Concurrent and. discriminant validity evidence for the ucla loneliness scale. Journal Of Personality And Social Psychology, 39, 472-480.

Russell, D., Cutrona, C. E., Rose, J. \& Yurko, K. (1984). Social and emotional loneliness: an examination of weiss' typology of loneliness. Journal Of Personality And Social Psychology, 46(6), 1313-1321.

Saunders, M., Lewis, P., \& Thornhill, A. (2009). Research methods for business students (5th Ed.). London: Prentice Hall.

Schmidt, N. ve Sermat, V. (1983). Measuring loneliness in different relationships. Journal Of Personality And Social Psychology, 44(5), 1038-1047.

Song, Ji, Hoon; Joo, Baek-Kyoo (Brian) \& Chermack, J. T. (2009), The dimensions of learning organization questionnaire (dloq): a validation study in a korean Context. Human Resource Development Quarterly, 20 (1), 43-64.

Stroebe, W., Stroebe, M., Abakoumkin, G. \& Schut, H. (1996). The role of loneliness and social support in adjustment to loss: a test of attachment versus stress theory. Journal of Personality and Social Psychology. 70 (6), 1241-1249.

Şişman M. \& Turan S. (2004). Bazı örgütsel değişkenler açısından çalışanların iş doyumu ve sosyal - duygusal yalnızlık düzeyleri (MEB Şube Müdür Adayları Üzerinde Bir Araştırma). Osmangazi Üniversitesi Sosyal Bilimler Dergisi, 5(1) , 117-128. 
Tabancalı, E. \& Korumaz, M. (2014), İl eğitim denetmenlerinin iş yerinde yalnızlıklarının incelenmesi. Akdeniz Ĕgitim Araştırmaları Dergisi, 15, 31-40.

Yang, B. (2003). Identifying valid and reliable measures for dimensions of a learning culture. Advances in Developing Human Resources 5(2), 152-162.

Yılmaz, E.\& Aslan, H. (2013). Öğretmenlerin iş yerindeki yalnızlıkları ve yaşam doyumları arasındaki ilişkinin incelenmesi. Pegem Journal Of Education \& Instruction, 3(3), 59-69.

Yüksel, M. Y., Özcan, Z. \& Kahraman, A. (2013). Orta yaş öğretmenlerinin yalnızlıklarının bazı değişkenler açısından incelenmesi. Eğitim ve Öğretim Araştırmaları Dergisi, 2(4), 277-285.

Weiss, R. (1973). Loneliness: The Experience Of Emotional And Social Isolation, Cambridge, MA: The MIT Press.

Weiss, R. S. (1987). Refections on the present state of loneliness research. Journal of Social Behaviour And Personality, 2, 1-16.

Wright, S. L. (2005). Loneliness in the workplace (Unpublished Doctoral Dissertation). University of Canterbury, Christchurch, New Zealand.

Wright S. L.; Burt C. D. B. \& Strongman K. T. (2006). Loneliness in the workplace: construct definition and scale development. New Zealand Journal Of Psychology, 35(2), 59-68. 